The Golden \& the

\title{
Brazen World
}

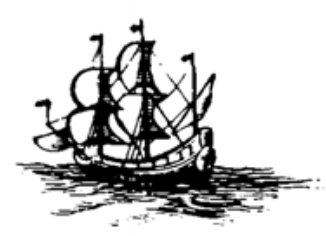

PUBLISHED UNDER THE AUSPICES OF THE

WILLIAM ANDREWS CLARK MEMORIAL LIBRARY

UNIVERSITY OF CALIFORNIA, LOS ANGELES 


\author{
Publications from the \\ CLARK LIBRARY PROFESSORSHIP, UCLA
}

1.

England in the Restoration and Early Eighteenth

Century: Essays on Culture and Society

Edited by H. T. Swedenberg, Jr.

2.

Illustrious Evidence

Approaches to English Literature of the

Early Seventeenth Century

Edited, with an Introduction, by Earl Miner

3.

The Compleat Plattmaker

Essays on Chart, Map, and Globe Making in England

in the Seventeenth and Eighteenth Centuries

Edited by Norman J. W. Thrower

4.

English Literature in the Age of Disguise

Edited by Maximillian E. Novak

5.

Culture and Politics

From Puritanism to the Enlightenment

Edited by Perez Zagorin

6.

The Stage and the Page

London's "Whole Show" in the

Eighteenth-Century Theatre

Edited by Geo. Winchester Stone, Jr.

7.

England's Rise to Greatness, 1660-1763

Edited by Stephen B. Baxter

8.

The Uses of Science in the Age of Newton

Edited by John G. Burke

9.

Studies in Eighteenth-Century

British Art and Aesthetics

Edited by Ralph Cohen

10.

The Golden \& The Brazen World

Papers in Literature and History, 1650-1800

Edited by John M. Wallace 


\section{THE GOLDEN \& \\ THE BRAZEN WORLD \\ Papers in Literature and History, 1650-1800}

Edited by

JOHN M. WALLACE

Clark Library Professor, 1982-1983 


\author{
University of California Press \\ Berkeley and Los Angeles, California \\ University of California Press, Ltd. \\ London, England
}

Copyright ( 1985 by The Regents of the University of California

Library of Congress Cataloging in Publication Data

Main entry under title:

The Golden \& the brazen world.

Contents: Need Clio quarrel with her sister muses? /

Cleanth Brooks - "That sober liberty" : Marvell's

Cromwell in 1654 / Derek Hirst - Dryden in 1678-1681 /

Phillip Harth - [etc.]

1. Literature and history-Addresses, essays, lectures.

I. Wallace, John M., 1928-

PN50.G6 $1985 \quad 809$

ISBN 0-520-05401-6

84-16233

Printed in the United States of America 